Utah State University

DigitalCommons@USU

1986

\title{
Leaf morphology plasticity in response to light environment in deciduous tree species and its implication on forest succession
}

\author{
F. Goulet \\ P. Bellefleur
}

Follow this and additional works at: https://digitalcommons.usu.edu/aspen_bib

Part of the Forest Sciences Commons

\section{Recommended Citation}

G. Goulet, P. Bellefleur. 1986. leaf morphology plasticity in response to light environment in deciduous tree species tree species and its implication on forest succession.Canadian journal of forest research. 16 (6): $1192-1195$

This Article is brought to you for free and open access by the Aspen Research at DigitalCommons@USU. It has been accepted for inclusion in Aspen Bibliography by an authorized administrator of DigitalCommons@USU. For more information, please contact

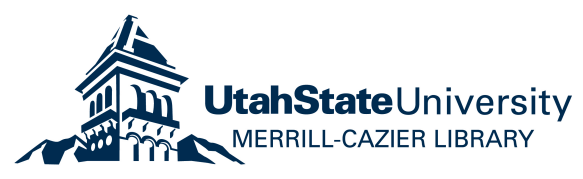




\title{
Leaf morphology plasticity in response to light environment in deciduous tree species and its implication on forest succession
}

\author{
France Goulet and Pierre Bellefleur \\ Centre de recherche en biologie forestière et Département des sciences forestières, Faculté de foresterie et de géodésie, \\ Université Laval, Ste.-Foy (Qué.), Canada GIK 7P4 \\ Received December 19, $1985^{1}$ \\ Accepted June 30, 1986
}

Goulet, F., and P. Bellefleur. 1986. Leaf morphology plasticity in response to light environment in deciduous tree species and its implication on forest succession. Can. J. For. Res. 16: 1192-1195.

Sun leaves of five deciduous tree species were shaded, while shade leaves of the same species were exposed to direct rays of the sun prior to budbreak and during leaf expansion. Thickness, area, and density thickness (fresh weight per unit area) were measured and compared with sun and shade leaves that were used as a control. These parameters showed a considerable differentiation in leaf structure both for the control and treated leaves, particularly with very tolerant (American beech and sugar maple) and intermediate (yellow birch) species; this was apparently associated with the prevailing light conditions around a particular leaf from budbreak and during its development. Intermediate (red maple) and very intolerant (trembling aspen) species did not show true sun and shade leaves. The impact of these leaf adaptations on forest succession is also discussed.

Goulet, F., et P. Bellefleur. 1986. Leaf morphology plasticity in response to light environment in deciduous tree species and its implication on forest succession. Can. J. For. Res. 16:1192-1195.

Des feuilles de lumière de cinq espèces feuillues ont été ombragées expérimentalement avant le débourrement des bourgeons jusqu'au développement complet des feuilles. Inversement, des feuilles d'ombre ont été exposées à la lumière. Certaines caractéristiques morphologiques, telles l'épaisseur, la surface et le poids frais par unité de surface ont été mesurées puis comparées avec des feuilles de lumière et des feuilles d'ombre témoins. Les différences observées dans la morphologie des feuilles témoins et traitées, particulièrement chez les espèces très tolérantes (hêtre à grandes feuilles et érable à sucre) et intermédiaire (bouleau jaune), semblent être associées aux conditions de lumière prévalant au moment du débourrement des bourgeons et pendant le développement des feuilles. Les espèces intermédiaire (érable rouge) et très intolérante (peuplier faux-tremble) ne forment pas de vraies feuilles d'ombre et de lumière. L'impact de ces adaptations sur la succession forestière est aussi discuté.

\section{Introduction}

Leaves are the organs most widely involved in light perception and those that develop in shade exhibit different morphology, anatomy, and physiology than those that develop in sunlight, even if they are attached to the same plant (Weier et al. 1974). Light is thought to be one of the most important, if not the chief, factor in producing these leaf differences; hence, the terms "sun" leaves and "shade" leaves growing at different positions on the same plant (Whatley and Whatley 1980). Such differences in the adaptation of the photosynthetic apparatus of tree species have been reported by several authors (Wylie 1951; Anderson 1955; Björkman and Holmgren 1963a, 1963b; Jackson 1967; Lewis 1972; Boardman 1977). Recent interest has been directed towards a better knowledge of the morphological changes which occur in shade-grown leaves (McMillen and McClendon 1979, 1983; Duba and Carpenter 1980).

Most of the anatomical investigations of forest tree species have dealt with mature leaves and little attention has been paid to modifications in leaf structure induced by changes in light conditions prior to budbreak and during leaf expansion. The only investigations of this kind were made a long time ago (Isanogle 1944; Cormack and Gorham 1953).

The aim of this study is to compare response in morphology of sun and shade leaves to differences in light level in five species under field conditions. Indeed, it is still debatable whether mature leaves develop sun and shade characters as a result of the environment in which the leaves expand and mature, or if sun and shade characters are already predetermined in the bud. While Cormack and Gorham (1953) found that such characters are present in mature leaves of shrubs probably in response to differences in the environment at the time of leaf

\footnotetext{
${ }^{1}$ Revised manuscript received June 19, 1986.
}

expansion, there does not seem to be any recent study on the subject for forest tree species in situ.

\section{Materials and methods}

Data reported in this paper have been obtained from five forest tree species: yellow birch (Betula alleghaniensis Britton), American beech (Fagus grandifolia Ehrh.), trembling aspen (Populus tremuloides Michx.), red maple (Acer rubrum L.), and sugar maple (Acer saccharum Marsh.). On the scale very tolerant-tolerant-intermediateintolerant-very intolerant, Baker (1949) classifies American beech and sugar maple as very tolerant, red maple as tolerant, yellow birch as intermediate, and trembling aspen as very intolerant; however, the following year, Baker (1950) ranked red maple as intermediate, which is a more appropriate ranking for it on our moist site. In early April, prior to budbreak, trees from 5 to $15 \mathrm{~m}$ high of each species growing in the dense shade and other trees of comparable size and age found nearby on a clear-cut area were selected for this study in the Duchesnay Experimental Forest, $50 \mathrm{~km}$ west of Québec (Qué.), a yellow birchmaple forest (Grandtner 1966; Robitaille 1977).

About 20 buds on the periphery or the upper part of the crown of different trees were covered by an aluminium dish attached to the twigs with two nylon ties and supported $3-5 \mathrm{~cm}$ above them to avoid interference with the circulation of air. These resulting leaves are referred to as "shaded leaves" because they come from buds produced the previous year in direct sunlight but develop in artificially produced shade. The dishes were about $13 \mathrm{~cm}$ wide and $15 \mathrm{~cm}$ long, large enough to shade the new leaves as they expanded. The same number of control "sun leaves" were selected and left exposed to the direct rays of the sun. In some shade trees, "unshaded leaves" coming from buds produced the previous year under the shade, were artificially exposed to the sun by cutting branches above them and from the neighbor trees. Control "shade leaves" were left in dense shade. It is important to notice that the species involved in this experiment are thought to form both sun and shade leaves, while species in a great number of related studies are definitely sun or shade species.

Twenty leaves of each control and treatment were marked at the 

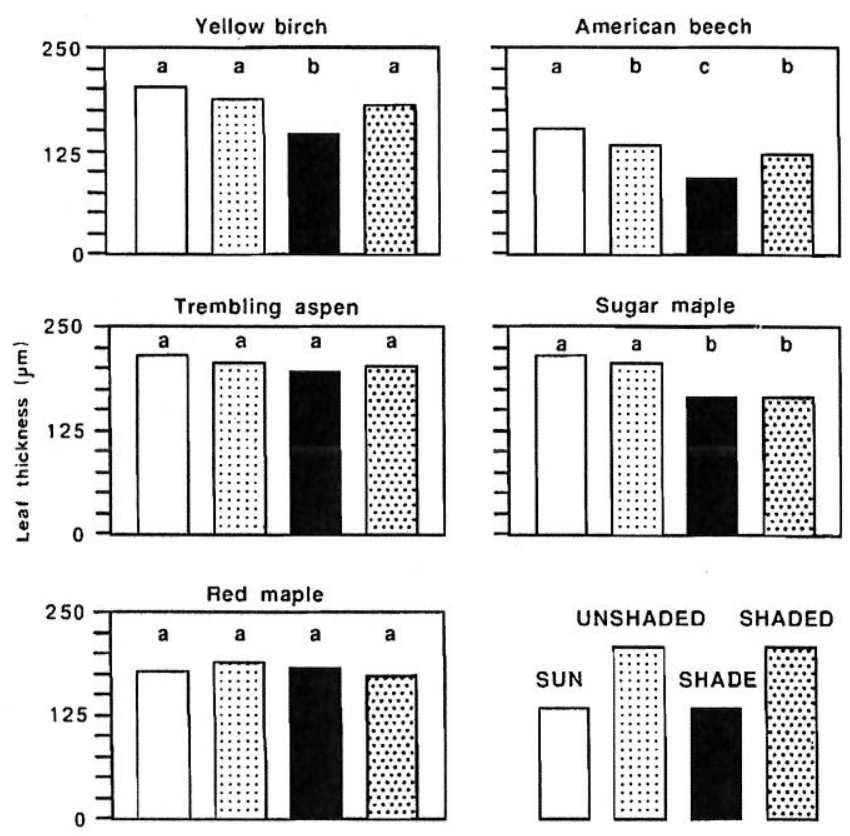

Fig. 1. The effect of light environment on the leaf thickness of five deciduous tree species. Bars with the same letter are not significantly different $(P \leq 0.05)$.

beginning of June. At the end of their growth, on July 30, 15 samples of sun leaves, shade leaves, shaded leaves, and unshaded leaves were collected for each species. Leaf thickness was measured with a mechanical micrometer (TESA, Switzerland) to the closest $2.5 \mu \mathrm{m}$ at the inner intersection of the main vein and the first secondary vein (trembling aspen, sugar maple, and red maple), and of the main vein and the third secondary vein (yellow birch and American beech). A portable area meter (Li-Cor model LI-3000) was used to measure leaf area to the nearest $1 \mathrm{~mm}^{2}$. These data were recorded in the field, on a portable microcomputer (Epson HX-20) and then transferred later on in the laboratory to an Apple III microcomputer for analysis. The petiole was removed and fresh weight was measured to the nearest $0.1 \mathrm{mg}$ (Mettler balance, model AE 50). Density thickness (fresh weight per area) was calculated (McClendon 1962); this is different from specific leaf weight (dry weight per area) and, according to McClendon (1962), the value of density thickness should give a good approximation of the leaf mean thickness. Indeed, as a measure of the metabolic potential (per unit area) of a leaf, density thickness is clearly believed to be better than simple leaf thickness, which includes unknown amounts of air space (McClendon and McMillen 1982). Light conditions, quantity and quality, were not measured since the objective was to determine whether or not there were responses in morphology between treatments before persuing the experimentation any further.

Analysis of variance was used to test leaf thickness, area, and density thickness $(P \leq 0.05)$. An analysis was computed for each variable between the six possible pairs of control and treatments: sun-unshaded, sun-shade, sun-shaded, unshaded-shade, unshaded-shaded, and shade-shaded leaves.

\section{Leaf thickness}

\section{Results}

Leaf thickness showed considerable variation among the studied species (Fig. 1). Differences between sun and shade leaves are generally recognized and comparisons between the different treatments show that no unique trend exists for all species. For trembling aspen and red maple, there are no significant differences among the different treatments, not even between control sun and shade leaves. However, yellow birch, American beech, and sugar maple have significantly thinner shade leaves than both sun and unshaded leaves. Shaded leaves
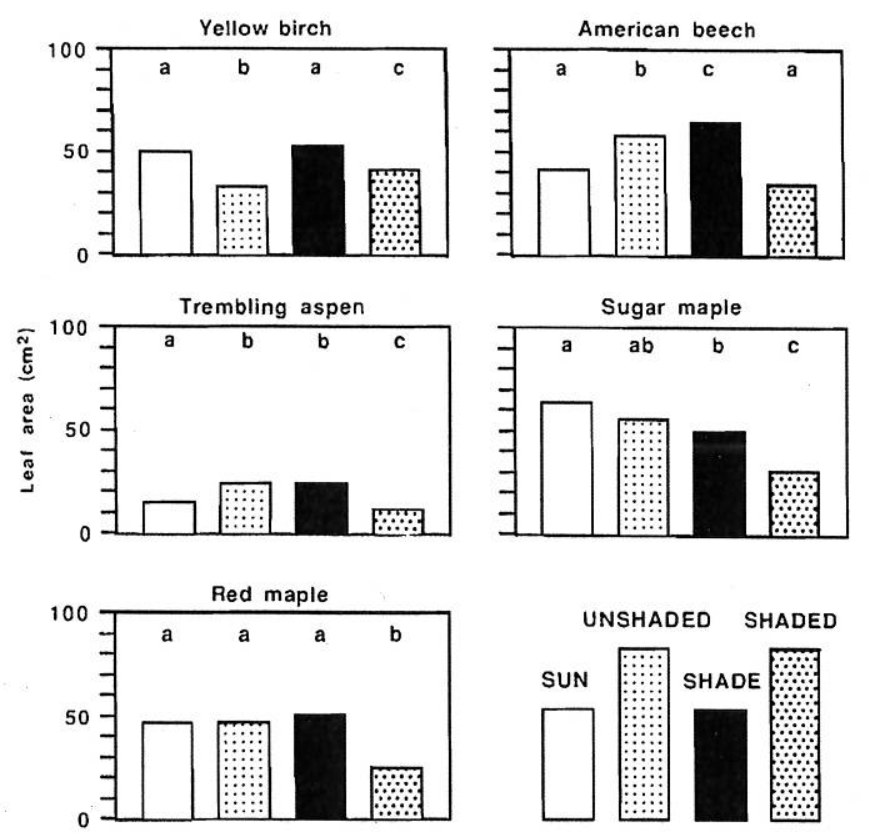

Fig. 2. The effect of light environment on the leaf area of five deciduous tree species. Bars with the same letter are not significantly different $(P \leq 0.05)$.

are significantly thinner than sun leaves for American beech and sugar maple, although shaded leaves had a close source of photosynthate from sun leaves on the same shoot. Unshaded leaves respond to their heightened light environment by increasing their thickness. In the shading treatment, the amount of light reaching shaded leaves being very reduced during the period of leaf expansion, thickness is also reduced in relation to sun leaves.

\section{Leaf area}

Figure 2 shows that leaf area is significantly different between sun and shade leaves with the exception of yellow birch and red maple, where differences are not significant. Shade leaves of all species have a larger area than sun leaves, with the exception of sugar maple with smaller shade leaves. For the treatments, while we did not record significant differences between sun and shaded leaves of American beech, shaded leaves of all other species are significantly smaller than sun leaves rather than the opposite. This might, however, be due to a too drastic change in light conditions induced by the treatment. Finally, unshaded leaves of yellow birch and American beech were significantly smaller than shade leaves, as we would expect from the controls.

\section{Leaf density thickness}

Sun leaves of all species have a greater density thickness than shade leaves, although not significantly so for trembling aspen (Fig. 3). Unshaded leaves have a significantly higher density thickness than shade leaves for all species and shaded leaves have a smaller value than sun leaves for all species except for trembling aspen; this is perhaps the best illustration that leaf structure is attributable to prevailing light conditions.

\section{Leaf thickness}

\section{Discussion}

Our results for yellow birch, American beech, and sugar maple agree with those of the literature: sun leaves of trees are always thicker than shade leaves (Acer platanoides L., Isanogle 1944; 10 species of deciduous trees, Wylie 1951; Fagus 


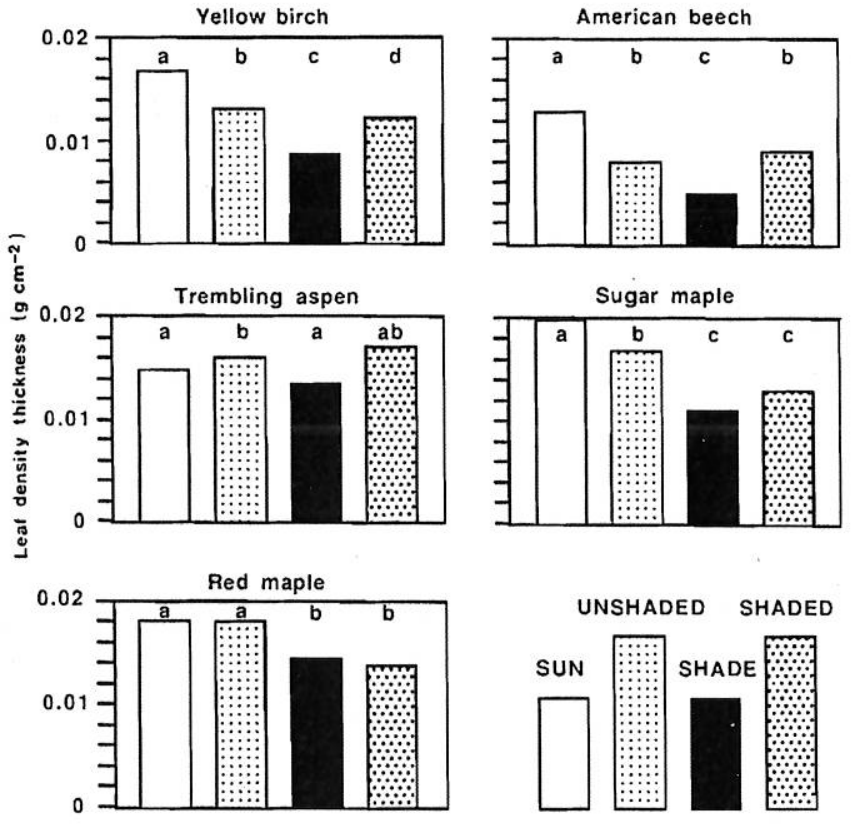

Fig. 3. The effect of light environment on the leaf density thickness of five deciduous tree species. Bars with the same letter are not significantly different $(P \leq 0.05)$.

silvatica L. and Quercus sessiliflora Salisb., Aussenac and Ducrey 1977; Platanus occidentalis L., Duba and Carpenter 1980; 8 species of trees, McClendon and McMillen 1982; 2 species of Betula, Nygren and Kellomäki 1983). The same trend exists for shrubs (Cormack and Gorham 1953; Anderson 1955). The similarity of our results with those of other authors demonstrates the validity of our measuring technique using a mechanical micrometer rather than microscope measurements; the method is much faster and not destructive of the observed material. It is important to notice that leaf thickness depends not only on individual cell dimensions but also on the numbers of cell layers. It would be helpful to determine whether there is any significant difference in this respect both between sun and shaded leaves and between shade and unshaded leaves. It is clear that sun and shade leaves changed their characteristic features when shade buds were allowed to develop in full sunlight while sun buds developed in the shade; hence, the firm belief that leaf thickness is associated with light conditions in the growing environment. Our results confirm the conclusion of Isanogle (1944) and Cormack and Gorham (1953), that differences in leaf expression are not predetermined in the bud. The greater thickness of sun leaves is so general that the lack of leaf differentiation in trembling aspen and red maple seems to indicate that there are no true sun and shade leaves in these two species.

\section{Leaf area}

Unlike leaf thickness, there is no unique trend for leaf area. With the exception of sugar maple, shade leaves have a larger blade area than sun leaves. The lack of a unique trend is also obvious in the literature: sun leaves are sometimes larger (Isanogle 1944; Tsel'niker 1977; McClendon and McMillen 1982) and sometimes smaller than shade leaves (Logan 1970; Tsel'niker 1977; Duba and Carpenter 1980; McClendon and McMillen 1982; Nygren and Kellomäki 1983). Tsel'niker (1977) observed that moderate shading causes significant increase in leaf area, while the area shrinks very much under conditions of strong shading. The evidence that leaf area is associated with light conditions is nonetheless as apparent as it was for leaf thickness. It seems that unshaded and shaded leaves, in respect to this parameter, did not respond in the direction of the controls to changes in light conditions, except in the case of sugar maple.

\section{Leaf density thickness}

Sun leaves always show a higher density thickness than shade leaves and we did not find any exception in the literature; in addition to authors mentioned in the previous two paragraphs, Fekete and Szujko-Lacza (1973), Gholz et al. (1976), and Jackson and Palmer (1977) found similar results. This parameter is as good as thickness in separating sun and shade leaves although it is more tedious to evaluate and the sample leaf has to be destroyed making it impossible to follow its progression throughout the season.

\section{Leaf plasticity and its implications on succession}

The clear response to the treatments indicates that American beech, yellow birch, and sugar maple have leaves with a high plasticity in relation to light conditions. In contrast, the apparent lack of adaptation to shade that we found for trembling aspen (very intolerant) and red maple (intermediate on our study site) could be explained by Smith's (1982) contention that plants exhibit basically two responses to shading: the "shade avoiders," exemplified by pioneer and intermediate tree species, and the "shade tolerators," exemplified by climax species. Indeed, being "shade avoiders," these two species would not have the ability to produce both sun and shade leaves. They would only show a small adjustment of their leaves when being slightly shaded; in dense shade, they would not be able to respond to the new light conditions and would eventually be succeeded by more tolerant species. This confirms what is observed in the field: trembling aspen is a pioneer species while red maple also appears at the beginning of succession but holds on much longer. On the other hand, American beech and sugar maple, both shade-tolerant species, and yellow birch, a moderately tolerant species, show the "shade tolerators" strategy. Not only do they form sun and shade leaves, but, furthermore, these morphological characteristics seem to adjust very well to the light environment and allow these species to compete successfully until climax. However, we have to keep in mind that such a phenomenon of light acclimation is believed to involve both physiological and anatomical changes (Nobel 1976; Bunce et al. 1977; Chabot et al. 1979). Nevertheless, Tsel'niker (1977) suggests that morphological indices could by themselves possibly be used as criteria indicating normal physiological activity in different species of plant under various light conditions.

The photosynthetic apparatus of the whole tree stand is, therefore, able to adjust itself to prevailing light conditions. Such morphogenesis in the characteristics of leaves is of importance in the successional potential of tree species. This adaptation phenomenon may also be competitively advantageous for some plants in the regeneration stage and a potential factor for increased production later on. The influence of light on forest crops, therefore, goes much further than being only a source of energy; it is also a major source of plant adaptation to the ever-changing forest environment.

\section{Acknowledgements}

We wish to thank J.-M. Lussier and C. Messier for invaluable technical help and G. J. Goth, C. Messier, and D. St.-Amand 
for reviewing the manuscript. Gratitude is also extended to the Natural Sciences and Engineering Research Council of Canada for the scholarship awarded to F. Goulet and to the Canadian Forestry Service for the research grant to P. Bellefleur. Furthermore, the Alcan Company kindly provided the aluminium material that was needed to carry out the experiment.

ANDERSON, Y. O. 1955. Seasonal development in sun and shade leaves. Ecology, 36: 430-438.

Aussenac, G., and M. Ducrey. 1977. Etude bioclimatique d'une futaie feuillue (Fagus silvatica L. et Quercus sessiliflora Salisb.) de l'Est de la France. Ann. Sci. For. 34: 265-284.

BAKER, F. S. 1949. A revised tolerance table. J. For. 47: 179-181. 1950. Principles of sylviculture. McGraw-Hill, Inc., Hightstown, NJ.

BJörkMAN, O., and P. Holmgren. 1963a. Adaptability of the photosynthetic apparatus to light intensity in ecotypes from exposed and shaded habitats. Physiol. Plant. 16: 889-914.

$1963 \mathrm{~b}$. Photosynthetic adaptation to light intensity in plants native to shaded and exposed habitats. Physiol. Plant. 19: 854-859.

BoARDMAN, N. K. 1977. Comparative photosynthesis of sun and shade plants. Annu. Rev. Plant. Physiol. 28: 355-377.

Bunce, J. A., D. T. Patterson, M. M. Peet, and R. S. Alberte. 1977. Light acclimation during and after leaf expansion in soybean. Plant Physiol. 60: 255-258.

Снавот, B. F., T. W. JuRiK, and J. F. Снавот. 1979. Influence of instantaneous and integrated light-flux density on leaf anatomy and photosynthesis. Am. J. Bot. 66: 940-945.

Cormack, R. G. H., and A. L. Gorham. 1953. Effects of exposure to direct sunlight upon the development of leaf structure of two deciduous shrub species. Can. J. Bot. 31: 537-541.

Duba, S. E., and S. B. Carpenter. 1980. Effect of shade on the growth, leaf morphology and photosynthetic capacity of an American sycamore clone. Castanea, 45: 219-227.

FeKeTE, G., and S. SzUjKo-LACZA. 1973. Leaf anatomical and photosynthetical reactions of Quercus pubescens Willd. to environmental factors in various ecosystems. Acta Bot. Hung. 18: 59-89.

Gholz, H. L., F. K. FITZ, and H. R. WARING. 1976. Leaf area differences associated with old-growth forest communities in the Western Oregon Cascades. Can. J. For. Res. 6: 49-57.

GrandTnER, M. M. 1966. La végétation forestière du Québec méridional. Presses de l'Université Laval, Québec (Que.).

ISANOGLE, I. T. 1944. Effects of controlled shading upon the development of leaf structure in two deciduous tree species. Ecology, 25: 404-413.

JACKson, J. E., and J. W. Palmer. 1977. Effects of shade on the growth and cropping of apple trees. 1. Experimental details and effects on vegetative growth. J. Hortic. Sci. 52: 245-252.

JACKSON, L. W. R. 1967. Effects of shade on leaf structure of deciduous tree species. Ecology, 48: 498-499.

LEWIS, M. C. 1972. The physiological significance of variation in leaf structure. Sci. Prog. (Oxford), 60: 25-51.

LOGAN, K. T. 1970. Adaptations of the photosynthetic apparatus of sun- and shade-grown yellow birch (Betula alleghaniensis Britt.). Can. J. Bot. 48: 1681-1688.

MCClendon, J. H. 1962. The relationship between the thickness of deciduous leaves and their maximum photosynthetic rate. Am. J. Bot. 49: 320-322.

McClendon, J. H., and G. G. McMillen. 1982. The control of leaf morphology and the tolerance of shade by woody plants. Bot. Gaz. (Chicago), 143: 79-83.

MCMillen, G. G., and J. H. McClendon. 1979. Leaf angle: an adaptive feature of sun and shade leaves. Bot. Gaz. (Chicago), 140: 437-442.

- 1983. Dependence of photosynthetic rates on leaf density thickness in deciduous woody plants grown in sun and shade. Plant Physiol. 72: 674-678.

NoBEL, P. S. 1976. Photosynthetic rates of sun versus shade leaves of Hyptis emoryi Torr. Plant Physiol. 58: 218-223.

NyGREN, M., and S. KellOMÄK1. 1983. Effect of shading on leaf structure and photosynthesis in young birches, Betula pendula Roth. and $B$. pubescens Ehrh. For. Ecol. Manag. 7: 119-132.

Rotitaille, L. 1977. Recherches sylvicoles sur les feuillus nordiques à la Station forestière de Duchesnay. For. Chron. 53: 201-203.

SmITH, H. 1982. Light, quality, photoperception, and plant strategy. Annu. Rev. Plant Physiol. 33: 481-518.

TSEL'NIKER, Y.L. 1977. Regulation of processes of $\mathrm{CO}_{2}$ exchange and morphogenesis in seedlings of forest trees under conditions of shading. Sov. Plant Physiol. 24: 43-48.

Weier, T. E., C. R. Stocking, and M. G. Barbour. 1974. Botany: an introduction to plant biology. 5th ed. John Wiley and Sons, New York.

Whatley, J. M., and F. R. Whatley. 1980. Light and plant life. Edward Arnold (Publishers) Ltd., London.

WyLIE, R. B. 1951. Principles of foliar organization shown by sun-shade leaves from ten species of deciduous dicotyledonous trees. Am. J. Bot. 38: 355-361. 